\title{
Effect of Mepacrine (Atebrin) on the Success of Antibacterial Treatment of Urinary Infections*
}

\author{
DINESH C. SHARDA†, D. CORNFELD, and ALEXANDER J. MICHIE
}

From the Nephrology Clinic and Surgical Service of the Children's Hospital of Philadelphia; the Department of Pediatrics; and the Harrison Department of Research Surgery, School of Medicine, University of Pennsylvania, U.S.A.

Despite the availability of potent antibacterial drugs the recurrence of urinary infections in childhood is depressingly high. Similarly necropsy studies fail to show any decrease in the incidence of pyelonephritis since the introduction of the antibiotics (Jackson, Dallenbach, and Kipnis, 1955). This failure is due to the capacity of micro-organisms to develop resistance to one or more antibacterial drugs.

Urgently needed is a chemotherapeutic procedure that will prevent the emergence of drug-resistant bacterial strains. Sevag has shown (Drabble and Sevag, 1962; Sevag and Ashton, 1964; Sevag, 1964) that the development of drug-resistant strains of Staphylococcus aureus, Esch. coli, and Aerobacter aerogenes can be prevented by the simultaneous administration of mepacrine (atebrin), or spermine with sulphathiazole, penicillin, erythromycin, novobiocin, streptomycin, tetracycline, or chloramphenicol. He also showed that specific and multiple drug-resistant strains of these organisms developed when they were grown with the antibacterial drug in the absence of mepacrine. Sevag believes that mepacrine and spermine combine with the bacterial desoxyribonucleic acid, and that this breaks the genetic code for the development of drug resistance.

\section{Subjects and Methods}

A group of therapeutic failures was selected, comprising 10 patients who had received, singly or in combination, 5 or more antibacterial drugs (Table). The ages of the 9 girls and 1 boy varied from 2 to 14 years. Intravenous urography combined with voiding cystograms had failed to show any anatomical obstruction to urine flow in all. A continuous infection was present in 3

\footnotetext{
Received September 22, 1965.

* This work was supported in part by research grant AM-2662 from the National Institute of Arthritis and Metabolic Diseases, and General Research Support Grant FR-05506, Public Health Service, and was read at a meeting of the British Association of Paediatric Surgeons in Edinburgh, July 1965.

$\uparrow$ Present address: The Institute of Child Health, Dilkhusa Street, Calcutta 17, India.
}

patients (Cases 1, 2, 10), and the remaining 7 had had at least one recurrent infection per year, despite a protracted antibacterial therapy programme (Michie, 1959). Antibacterial mepacrine therapy was instituted during a recurrent urinary infection in the 7 patients. A urinary infection was assumed to be present when 2 or more urine cultures grew the same bacteria. Urine cultures were obtained at 2-week intervals until the urine became sterile, then they were obtained at 3-month intervals. The antibacterial drug that caused the greatest retardation of growth in the culture media was used. The dosage varied from drug to drug and all patients weighing more than $80 \mathrm{lb}$. ( $36 \mathrm{~kg}$.) were given the same amount of drug as would be given to patients weighing $80 \mathrm{lb}$. (36 kg.). The daily dosage for a soluble sulphonamide was $200 \mathrm{mg} . / \mathrm{kg}$. day, for chloramphenicol and nalidixic acid it was $40 \mathrm{mg} . / \mathrm{kg}$. day, and for nitrofurantoin it was $6 \mathrm{mg}$. $/ \mathrm{kg}$. day. While the bacteria were in the urine, the drugs were given 3 times daily at 8 -hour intervals. About a month after the urine became sterile two-thirds of the original daily dose was given in 2 divided doses at 12-hour intervals. The daily dose of mepacrine was $4 \mathrm{mg}$. $/ \mathrm{kg}$. day in 2 divided doses at 12-hour intervals. Usually the mepacrine was stopped after 4 weeks of therapy, but in one case (Case 1) for psychological reasons alone it was given for 52 weeks. Once the urine was free of bacteria our routine long-term drug therapy programme (Michie, 1959) was followed. We thought that in this group of patients with drug-resistant urinary infections, any sterilization of the urine must be attributed to the combined antibacterial-mepacrine therapy.

\section{Results}

Nitrofurantoin and mepacrine eradicated a continuous Esch. coli-Kleb. aerobacter urinary infection which had lasted for 120 months in Case 1 (Table). Similarly liposulphafurazole and mepacrine sterilized the urine of Case 2 who had had a continuous Esch. coli-B. proteus urinary infection for 60 months. In Cases 3-8 with frequent recurrent urinary infections the combination of mepacrine with nitrofurantoin, chloramphenicol, triple sulphonamide or Lipogantrisin sterilized the urine for 8 or more months. In Cases 9 and 10, however, mepacrine 
TABLE

Effects of Combined Antibacterial and Mepacrine Therapy in Patients with Persistent Chronic Infections, and Patients with Multiple Recurrences

\begin{tabular}{|c|c|c|c|c|c|c|}
\hline \multirow{2}{*}{$\begin{array}{l}\text { Case } \\
\text { No. }\end{array}$} & \multirow{2}{*}{ Dominant Bacteria } & \multirow{2}{*}{$\begin{array}{l}\text { Drug Used with } \\
\text { Mepacrine }\end{array}$} & \multirow{2}{*}{$\begin{array}{l}\text { Months } \\
\text { of } \\
\text { Therapy }\end{array}$} & \multicolumn{2}{|c|}{ Months of Infection } & \multirow{2}{*}{ Results } \\
\hline & & & & $\begin{array}{c}\text { Before } \\
\text { Mepacrine }\end{array}$ & $\begin{array}{c}\text { After } \\
\text { Mepacrine }\end{array}$ & \\
\hline $\begin{array}{l}1 \\
2 \\
3 \\
4 \\
5 \\
6 \\
7 \\
8 \\
9\end{array}$ & $\begin{array}{l}\text { Esch. coli; Kleb. aerobacter } \\
\text { Esch. coli; B. proteus } \\
\text { Esch. coli; B. proteus } \\
\text { Enterococcus } \\
\text { Staphylococcus ( } \alpha \text {-haemolytic) } \\
\text { Enterococcus; Kleb. aerobacter } \\
\text { Enterococcus } \\
\text { Enterococcus; Esch. coli } \\
\text { Esch. coli; B. proteus }\end{array}$ & $\begin{array}{l}\text { Nitrofurantoin } \\
\text { Lipogantrisin } \\
\text { Nitrofurantoin } \\
\text { Nitrofurantoin } \\
\text { Triple Sulpha } \\
\text { Chloramphenicol } \\
\text { Lipogantrisin } \\
\text { Triple Sulpha } \\
\text { Nitrofurantoin }\end{array}$ & $\begin{array}{c}12 \\
6 \\
1 \\
0 \cdot 5 \\
6 \\
1 \\
1 \\
6 \\
2\end{array}$ & $\begin{array}{c}120 \\
60 \\
72 \\
24 \\
24 \\
12 \\
8 \\
2 \\
2\end{array}$ & $\begin{array}{l}0 \\
0 \\
0 \\
0 \\
0 \\
0 \\
0 \\
0 \\
8\end{array}$ & $\begin{array}{l}\text { All cultures sterile } 12 \mathrm{mth} \text {. } \\
\text { All cultures sterile } 7 \mathrm{mth} \text {. } \\
\text { All cultures sterile } 10 \mathrm{mth} \text {. } \\
\text { All cultures sterile } 12 \mathrm{mth} \text {. } \\
\text { All cultures sterile } 8 \mathrm{mth} \text {. } \\
\text { All cultures sterile } 12 \mathrm{mth} \text {. } \\
\text { All cultures sterile } 8 \mathrm{mth} \text {. } \\
\text { All cultures sterile } 8 \mathrm{mth} \text {. } \\
2 \text { sterile cultures while on } \\
\text { therapy; recurrence of } \\
\text { proteus } 1 \text { wk. after } \\
\text { stopping therapy } \\
\text { Recurrence of proteus } \\
\text { during } 4 \text { th week of } \\
\text { therapy }\end{array}$ \\
\hline
\end{tabular}

Cases 1, 2, and 10 had continuous infection.

with nitrofurantoin and mepacrine with chloramphenicol failed to affect significantly the urinary infection. In both of these patients Esch. coli alone was found in the urine immediately before, and only $B$. proteus was found immediately after, the termination of combined antibacterial-mepacrine therapy.

Mepacrine caused a few minor toxic symptoms in our patients. One patient developed an unpleasant deep yellow pigmentation of her skin. The colour first upset the patient's mother and then the child. A generalized morbilliform rash occurred in another patient. Moderately severe nausea and vomiting occurred in 2 patients. All of these disturbances disappeared within 2 to 4 weeks after stopping mepacrine therapy.

\section{Discussion}

The fact that a chronic urinary infection causes few if any symptoms makes both the assessment and treatment of the problem difficult. Some authorities are satisfied with their efforts, while others (Kass, 1955) state that the bacteriological cure rate is not more than $20 \%$ despite major advances in antibacterial therapy. An important reason for drug failure is the development of drug-resistant bacterial strains. Mepacrine, by combining with the bacterial desoxyribonucleic acid, should retard or prevent the emergence of drug-resistant bacteria.
This was accomplished in Cases 1-8, but not in Cases 9 and 10, though the Esch. coli in both these was replaced by $B$. proteus (both patients had had proteus urinary infections previously).

\section{Summary}

Combined antibacterial-mepacrine therapy eradicated the urinary infection in 8 of 10 patients in whom previous treatment had failed.

The authors are indebted to Dr. M. G. Sevag, Department of Microbiology, School of Medicine, University of Pennsylvania.

\section{REFERENCES}

Drabble, W. T., and Sevag, M. G. (1962). Prevention of the development of microbial resistance to drugs. In Antimicrobial Agents and Chemotherapy-1962, p. 649. American Society for Microbiology, Ann Arbor, Michigan.

Jackson, G. G., Dallenbach, F. D., and Kipnis, G. P. (1955). Pyelonephritis: correlation of clinical and pathological observations in the antibiotic era. Med. Clin. N. Amer., 39, 297.

Kass, E. H. (1955). Chemotherapeutic and antibiotic drugs in the management of infections of the urinary tract. Amer. F. Med., $18,764$.

Michie, A. J. (1959). Chronic pyelonephritis mimicking ureteral obstructions. Pediat. Clin. N. Amer., 6, 1117.

Sevag, M. G. (1964). Prevention of the emergence of antibiotic resistant strains of bacteria by Atabrine. Arch. Biochem., 108, 85.

- , and Ashton, B. (1964). Prevention of antibiotic and sulfonamide resistance by Atabrine. In Antimicrobial Agents and Chemotherapy-1964, p. 410. American Society for Microbiology, Ann Arbor, Michigan. 